\title{
The Development of an E-Learning-Based Learning Service for MKDP Curriculum and Learning at the Indonesia University of Education
}

\author{
Dr. Rusman, M.Pd. \\ Chairman of the Graduate Study Program Development Curriculum, Indonesia University of Education
}

\begin{abstract}
E-learning is a general term used to refer to computer-enhanced learning based that facilitates whoever, wherever, and whenever the person is to be able to learn more fun, easier and cheaper by using Internet. In other words, E-learning is the use of network technologies to create, foster, deliver, and facilitate learning, anytime and anywhere. It also means a learning facility that uses electronic devices such as LAN, WAN, or Internet to give lectures, to interact, or to guide and monitor the students. E-learning is naturally suited to distance learning and flexible learning. This learning is an asynchronous or self-directed; self-paced activity that is used in order for the students to obtain learning materials by using electronic computer devices that are designed to help the students to get learning materials needed. Asynchronous consists of learning that is stand-alone. Asynchronous eLearning can be delivered through the web, via an Intranet, or by way of an extranet.The Curriculum and Education Technology Department of Indonesia University of Education is now trying to design and to use this E-learning as a supplement in MKDP curriculum and learning subjects. The department has been trying to develop the research on E-learning by using research method and development. The instrument used comprises questionnaires meanwhile the data analysis used are descriptive data analysis. Based on the result of the research, it shows that e-learning program is able to assist the lecturers of MKDP curriculum and learning subjects to improve their ability in designing and developing learning design based on electronic devices by using models and program software.
\end{abstract}

\section{A. INTRODUCTION}

The development of computer technology has significantly influenced many aspects of life including education. There are so many learning models that use computer such as Computer-Assisted Instruction (CAI), Computer Based Instruction (CBI), e-learning (electronic learning) and e-teaching (electronic teaching). These models of learning enable both the lecturers and the students to comprehend teaching materials directly from educational web sites offered by the institution as one of learning sources. By using e-learning, the students are expected to access and to use this learning facility to learn independently. E-learning can involve a greater variety of equipment than online training or education, for as the name implies, "online" involves using the Internet or an Intranet. CD-ROM and DVD can be used to provide learning materials.

The development of Internet technology has made a distance and flexible learning possible to exist. The advantage of electronic learning, web-based training (WBT) or web based education (WBE) and virtual campus is that the teaching and learning can be done wherever and whenever. It overcomes timing, attendance and travel difficulties. The students can access to the learning sources anytime and anywhere, more open, more comfortable, more fun, faster and without any limits. By using e-learning, the lecturers and the students are able to conduct a conference or discussion using electronic conference without having to meet face to face.

The advantage of e-learning program:

1. It is very dynamic (this program can be presented in many ways interestingly, attractively, and interactively)

2. It has no time limit operation so that both the lecturers and the students have no limitation in obtaining and searching learning sources needed.

3. It facilitates the students to learn individually. Every student is given the right to choose his or her own format of learning that is suitable with his or her background.

4. It is comprehensive to provide any kinds of learning activities and sources that enable the students to pick any formats, methods of learning, and exercises provided.

Viewing the advantages of e-learning, MKDP curriculum and learning at the Indonesia University of Education expects that this program is able to improve the quality and learning result of the students so that at the end of teaching and learning process, they are able to graduate not only on time but also having good quality.

One of the policies and programs of Indonesia University of Education (UPI) 2010-2015 is to develop distance learning systems that employ the ICT possessed by the campus. UPI has been targeting ten program studies to use ICT networking systems to conduct e-learning lecture systems.

In order to be able to carry out the learning programs by using e-learning facilities, the team consists of the experts of Internet Technology, the experts of education technology, and the experts of ICT is formed to 
maintain the smoothness and the continuity of the program. Therefore, in line with the development of leaning based on e-learning program, the writer is trying to propose a research entitled The Development of an ELearning Based Learning Service For MKDP Curriculum and Learning at The Indonesia University of Education.

\section{B. THEORETICAL FRAMEWORK}

\section{Web Based Learning}

Web based learning that is popularly known as web-based training (WBT) or web-based education (WBE) refers to the application of web technology in education. In another words, any teaching and learning activities that employ Internet technology that facilitate the learning process of the students can be categorized as WBT or WBE.

This program is used to facilitate whoever, wherever, and whenever the person is to be able to learn more fun, easier and cheaper by using Internet. In another words, E-learning is the use of network technologies to create, foster, deliver, and facilitate learning, anytime and anywhere. It overcomes timing, attendance and travel difficulties. The students can access to the learning sources anytime and anywhere, more open, more comfortable, more fun, faster and without any limits.

Many parties have tried to use web technology unwisely. They only use this media to download the materials needed as a reading task or to submit chapter reports or any other assignments via Internet without any further actions. If the technology is only used by this level, of course the learning process will not be optimum. The expected learning process in class via web is quite hard to manage compared to a common regular class. As monitoring the learning process using web involves many aspects such as special instructional designs that are able to invite the students to participate actively and willingly in any learning activities without the existence of his or her lecturers near them.

\section{2. e-Learning}

Based on Koran Jaya Kumar C. (2002) e-learning is the learning activities that use electronic devices such as LAN, WAN, or Internet to give lectures, to interact, or to guide and monitor the students. Some experts say that E-learning is naturally suited to distance learning and flexible learning. Meanwhile Dong (in Kamarga, 2002) defines E-learning as asyncronous learning activity by using electronic devices that facilitate the students to get any source of learning and reading material needed to help them to study better. E-learning is asynchronous or self-directed; self-paced activity that is used in order for the students to obtain learning materials by using electronic computer devices that are designed to help the students to get learning materials needed. Asynchronous consists of learning that is stand-alone. Asynchronous eLearning can be delivered through the web, via an Intranet, or by way of an extranet.

Soekartawi, (2003) define E-learning as a generic term for technologically supported learning using an array of teaching and learning tools as phone bridging, audio and videotapes, teleconferencing, satellite transmissions, and the more recognized web-based training or computer aided instruction also commonly referred to as online courses.

The main difference between traditional learning and E-learning lies on the main actor or the main focus in the process of teaching and learning activity. In a common or regular class, the main actor is a teacher or a lecturer meanwhile in E-learning class; the main actor is the student. The learning process of E-learning is asyncronous learning activity that forces the students to stand-alone in self-directed or self-paced activities.

\section{a. The Supporting Technology of E-Learning}

In practice the use of E-learning needs technology. There are some terms related to E-learning and technology; computer based learning (CBL) that is a full version of learning using computer devices; and computer assisted learning $(\mathrm{CAL})$ that is the use of computer as the main media in learning process.

The use of technology in education has evolved from time to time. Nowadays, there are two main terms in the use of technology in education: (a) technology based learning and (b) technology based web learning. The use of technology as the source of learning includes the use of audio information technologies (radio, audiotapes, voicemail telephone) and video information technologies (videotape, video text, video messaging). As for technology based web learning includes the use of bulletin board, Internet, e-mail, and tele-collaboration.

In everyday teaching and learning activities, the combination of technology based learning and technology based web learning is commonly used (audio/data, video/data, and audio/video). This type of technology has been used in distance education so that the students and the lecturers are able to solve distant problem by using the benefit of this E-learning technology.

Based on Onno W Purbo (1997), there are five applications of Internet standard that can be used in education among others: e-mail, mailing list (milis), news group, file transfer protocol (FTC), and world wide web (www). Rosenberg (2001) categorizes E-learning into three basic categories, that is, first e-learning is web designed program so that it can do a fast self-recovery, store the program or file and review it in another time. Second, E-learning is sent toward the users through the computer that uses a based internet technology. Third, E- 
learning focuses on the broad view of learning, learning solution that is more advanced that the traditional one.

There are some alternative paradigm in education based Internet. One of them is 'dot.com. educational system' (Kardiawarman, 2000). This paradigm integrates several systems; those are first virtual teacher resources, second, virtual school system, and third, cyber educational resources system or dot com learning resources system.

\section{b. The Development of E-Learning Model}

Based on Haughey (in Rusman, 2011) there are at least three possibilities of the development of E-learning based education, namely web course, web centric course, and web enhanced course.

Web course is the use of internet to support distant education need, for example, the avaibility of learning material, discussion, consulting, giving tasks and assignment, tests, and any other.

Web centric course is naturally suited to distance learning and flexible learning, but can also be used in conjunction with face-to-face conventional teaching. While some programs require students to attend some campus classes or orientations, many are delivered completely online.

Web enhanced course is the use of internet to support the improvement of teaching and learning activity in the conventional classes. This course offers online advising and registration, e-counselling, and any other services to increase the students's proficiency.

\section{RESEARCH FINDINGS}

The findings of the research show that the development of e-learning service can be done through web course, web centric course, and web enhanced course. The lecturers that use e-learning service can employ selective model (if the computer's availibility is limited only to one unit), sequential model (if there are more than one unit of computer; two to three units), static station model (the computer's availibility is very limited and there is any use of other learning source).

Following are the responses of the lecturers toward the use of e-learning:

1. The development of e-learning should cover:

a. the aim or competency of learning that wants to be achieved $(89.35 \%)$

b. the detail learning material explanation $(85.75 \%)$

c. tasks and assignments that should be accomplished by the students $(78.6 \%)$

d. tests that should be accomplished by the students $(57.1 \%)$

e. responses from tasks, assignments and tests $(75 \%)$

f. reading sources as the supporting material $(71.4 \%)$

g. program, website or sites that can be linked $(75 \%)$

2. the explanation is presented in popular language that is easy to understand $(75 \%)$

3. the language that is used in e-learning is expected to brief and clear $(92.9 \%)$

4. the presentation of program is selected based on the aim or learning competency that wants to be achieved $(89.3 \%)$

5. the explanation of the material is designed based on the aim or learning competency that wants to be achieved $(89.3 \%)$

6. the presentation of material given is followed by the activities such as practice, tasks and assignments and tests $(71.4 \%)$

7. the presentation and the activities such as practice, tasks and assignments and tests are carried out at once $(71.4 \%)$

8. the fonts used in the presentation of the material should be simplified and clear $(60.7 \%)$

9. Presentation materials should not be written in bright or spotlight colors; the preferred colors are the pastel ones $(42.9 \%)$.

10. e-learning is presented with pictures and any other elements that motivate and attract the students' curiosity of learning $(60.7 \%)$

11. the presentation of headline is simple and clear $(60.7 \%)$

12. the signs/symbols/icons should be clear and avoid ambiguity for public's understanding $(89.3 \%)$

13. the use of pictures or illustration should be balance therefore it will not take over the main function of the web as the source of learning $(50 \%)$

14. e-learning is expected to present information about learning target or learning comptency that has been achieved by the students $(92.9 \%)$

15. the response is needed to give feed back to the students about the material or lesson given $(71.4 \%)$

16. e-learning is developed by using model that is easy to comprehend $(42.9 \%)$

The result of the pre-finding has been displayed in table 1, see appendix:

\section{DATA ANALYSIS}

Based on the theoretical framework it is discovered that there are three models that can be used to develop e- 
learning, namely:

Web course is the use of internet to support distant education need, for example, the avaibility of learning material, discussion, consulting, giving tasks and assignment, tests, and any other.

Web centric course is naturally suited to distance learning and flexible learning, but can also be used in conjunction with face-to-face conventional teaching. While some programs require students to attend some campus classes or orientations, many are delivered completely online.

Web enhanced course is the use of internet to support the improvement of teaching and learning activity in the conventional classes. This course offers online advising and registration, e-counselling, and any other services to increase the students's proficiency.

Those models can be chosen based on the characteristics or learning competencies that want to be achieved.

The respondents (the lecturers) argue that the components presented in e-learning are suitable for developing e-learning based program because they consist of not only the explanation of the material is designed based on the aim or learning competency that wants to be achieved but also the presentation of material given is followed by the activities such as practice, tasks and assignments and tests in one package. This implies that elearning matches the criteria of supporting material or an additional learning source. The existence of e-learning is expected to be able to improve the quality and learning result of the students so that at the end of teaching and learning process, they are able to graduate not only on time but also having good quality.

In line with the previous paragraph, the use of e-learning is also expected to enhance the capacity and quality of supporting infrastuctures used in an E-Learning-Based Learning Service For MKDP Curriculum and Learning at The Indonesia University of Education.

\section{E. CONCLUSION AND SUGGESTION}

1. There are three models that can be used to develop e-learning in an E-Learning-Based Learning Service For MKDP Curriculum and Learning at The Indonesia University of Education, namely: Web course, Web centric course and Web enhanced course. Those models can be chosen based on the characteristics or learning competencies that want to be achieved.

2. to promote the competencies of UPI lecturers in developing teaching materials, there must be clear objectives or types of competencies that supposed to be accomplished. Moreover the followings are the components that are used in developing e-learning:

a. the aim or competency of learning that wants to be achieved

b. the explanation of material of learning

c. tasks and assignments that should be accomplished by the students

d. tests that should be accomplished by the students

e. responses from tasks, assignments and tests

f. reading sources as the supporting material and program, website or sites that can be linked

3. to promote the competencies of lecturers in designing teaching materials, there must be clear ideas about the type of language programming that will be used, that is, by using front page, moodle, SAS, MySQL or any other softwares. The followings are the criteria and the formats of e-learning:

a. the presentation of program is selected based on the aim or learning competency that wants to be achieved

b. the language that is used in e-learning is expected to brief and clear

c. the format font used in the presentation of the material should be simplified and clear, the color used in the presentation of the material should use cold colors, and the signs/symbols/icons should be clear and avoid ambiguity for public's understanding

d. e-learning is presented with pictures and jokes or any other elements that motivate and attract the students' curiosity of learning

e. e-learning is expected to present information that can presented by using websites or sites that can be linked or accessed.

4. to enhance the capacity and quality of supporting infrastuctures used in an E-Learning-Based Learning Service For MKDP Curriculum and Learning at The Indonesia University of Education, the institution should provide a good and reliable lab computer to support e-learning program.

5. to provide human resources for research and development of e-learning. To achieve that, human resources are needed to be capable of:

a. System/information engineering and modelling.

b. Software requirements analysis.

c. Design. Design processes involve the conversion of needs to characteristic forms that comprehend a software before the writing of the program (coding) begins.

d. Coding. Designs should be changed so as to be forms that are understood by the computer. 
e. Testing. After the program code has been made, the program can be run.

In line with the conclusion presented above, a number of suggestions can be considered in research and further developments;

1. The development of e-learning must be conducted by paying attention to learning components.

2. The development of e-learning services should be carried out by using popular programming languages so as to enable students to understand; such programs are front page or moodle for designs and MySQL for database engines, presenting pictures to complete e-learning programming, designed for open access and used as both the main source and an enrichment in learning activities.

\section{BIBLIOGRAPHY}

Cisco (2001). E-learning: Combines Communication, Education, Information, and Training. Avaliabe at [Online] htt://www.cisco.com/warp/public/10/ wwtraining/e-learning.

Kamarga, Hansiswany, (2002). Belajar Sejarah Melalui E-learning. Jakarta : PT. Intimedia.

Kardiawarman, (2000). Penerapan Teknologi Informasi dalam Pendidikan Masyarakat. Jurnal Teknodik. Edisi ke-12/VII/Oktober/2000

Koran, Jaya Kumar C. 2002. Aplikasi E-Learning dalam Pengajaran dan Pembelajaran di Sekolah Malaysia.

Office of Education Technologi (2001). E-learning: Putting a World-Class Education at the Fingertips of All Children. Availabe at [Online] http://www.ed.gov/tecnology/elearning.

Onno W. Purbo, (1997). Usaha Mengamankan Internet bagi Dunia Usaha. Tersedia:http://onno.vlsm.org/v09/onno-ind-1/network/network- security/ usaha-mengamankaninternet-bagi-dunia-usaha-04-1997.rtf.

Rosenberg (2001). The Online Learning Handbook: Developing and Using Web Based Learning. Londong: Kogan Page.

Rusman (2011) Pembelajaran Berbasis Teknologi Informasi dan Komunikasi. Jakarta. Rajawali Pers. PT. RajaGrafindo Persada.

Soekartawi. 2003. Prinsip Dasar e-Learning: Teori dan Aplikasinya di Indonesia Jurnal Teknodik, Edisi No.12/VII/Oktober/2003

The author is Chairman of the Program Graduate School Curriculum Development (SPs) Indonesia University of Education. Born in Indramayu on $5^{\text {th }}$ of May 1972. History of Education initiated formal from SDN Kedokan Bunder III of 1985, SMPN Krangkeng 1988, SPGN Indramayu State in 1991, a Bachelor of Education Teachers' Training College Bandung on Department of Curriculum and Educational Technology, 1997. Master of Education in Prodi Development Curriculum Graduate Program UPI 2002. In March 2007 Author Achieved Doctoral degree Cum Laude with the Graduate School Curriculum Development Division (SPs) Indonesia University of Education.

Author of Teaching in S3 IN Subjects: Development of Basic Education Curriculum, Curriculum implementation, in S2 AT Course: Basic Education Curriculum, Information Systems Education, Curriculum Implementation, And Learning Through Media, in S1 in the Course Models of Learning, Computer Based Learning, Learning Media, Media TV/Video, And Curriculum and Learning.

Is the author of Curriculum Development in 2013 in Puskurbuk Kemendikbud Jakarta (2010-2012), guest speaker at the 2013 National Curriculum Implementation Agency for Education and Culture of Human Resource Development and Education Quality Assurance Kemendikbud Jakarta (2013-2014), Chairman of the Indonesian Association of Curriculum Development (HIPKIN) Region West Java (period 2013-2018), Being a Teacher Certification Assessor Position hearts, assessors Lecturer Workload And Also Actively Research in the Field of Curriculum and Educational Technology. Wrote an article in the Journal Various Both local and national as well as Active Resource person hearts upgrading activities, seminars, workshops and workshops of Curriculum and Educational Technology Good Local, national, and international levels.

Essay form that has published books of which is: Management Curriculum Development: Theory and Practice Application of SBC (PT. Sarana Panca Karya Nusa-Bandung), Curriculum and Learning (Rajawali Press-Jakarta), Educational Technology: Region and It's Application (Pustekkom-Jakarta), Models of Learning: Developing a Professional Teacher (Rajawali Press-Jakarta), Management Curriculum: Grade School Management Series (Rajawali Press-Jakarta), Learning-Based Information and Communication Technology (Rajawali Press-Jakarta), Learning and Computer-Based Learning (Alfabeta Bandung), and Integrated Thematic Learning: Theory, Practice, and Assessment (Press-Jakarta Eagles).

Author now staying at Jln. Geger Kalong Tengah No. 28 A 40154 Bandung West Java, Indonesia. 